\title{
Application of Lignocellulosic Waste for the Production of Laccase in Solid State Fermentation
}

\author{
Dr.Reshma Jaweria ${ }^{1} \mid$ Parwez Qayum ${ }^{2}$
}

1Department of Biotechnology, Maulana Azad College of Arts, Science and Commerce, Aurangabad, Maharashtra, India ${ }^{2}$ Department of Microbiology, Maulana Azad College of Arts, Science and Commerce, Aurangabad, Maharashtra, India

\section{To Cite this Article}

Dr.Reshma Jaweria and Parwez Qayum, "Application of Lignocellulosic Waste for the Production of Laccase in Solid State Fermentation”, International Journal for Modern Trends in Science and Technology, Vol. 07, Issue 01, January 2021, pp.141-145.

\section{Article Info}

Received on 11-December-2020, Revised on 30-December-2020, Accepted on 06-January-2021, Published on 19-January-2021.

\section{ABSTRACT}

Laccase from fungi have attained considerable attention due to the involvement in transformation and degradation of many polymers, ring cleavage of aromatic compounds and many phenolic compounds with the help of reduction of oxygen to water. Two fungal species were (Pleurotus. ostreatusand Pseudolagarobasidium acaciicola) used to study the production of laccase by solid state fermentation method on different lignocellulosic waste like rice bran, rice husk, wheat bran, and wheat straw. Presence of cellulose, lignin and hemicellulose in different lignocellulosic waste are rich in nutrients which promotes fungal growth in solid-state fermentation. From results it was confirmed that the rice bran produces higher concentration of laccasethan other lignocellulosic substrate.

KEYWORDS: Fungus, Laccase, Fermentation, Solid state Bioprocessing

\section{INTRODUCTION}

Laccase enzymes can obtained from higher plants, insects, bacteria and fungi [15].Laccases (1.10.32, p-diphenol: oxygen oxidoreductases) are produced from basidiomycetous(white rot fungi) and ascomycetousfungibelongs to the multicopper oxidases containing four copper atoms in the catalytic centre.This enzyme catalyse several phenolic compounds, aromatic amines, thiols with some inorganic compounds with oxygen as an electron acceptor [1].Laccases are having ability to remove xenobiotics substances from the environment and produce such compounds which are involved in bioremediation processes. With such properties these enzyme have attracted many researchers for it potential applications in pharmaceuticals (transformation of steroids, antibiotics), cosmetic, paper industry (bio-bleaching and bio-pulping), food industry, chemical industry (detoxification), textile (decolorization), nano-biotech and in controlling environmental pollution globally[17].

Earlier submerged fermentation were in process for the fermentation of most of the enzymes including laccase. Now trend have changes as the concept of utilization of lignocellulosic waste were carried by solid state fermentation (SSF). In SSF microorganisms are grown on natural substance as solid support in the absence of water. For production of Laccase enzymes, fungus can be growth on different lignocellulosic waste, which contain significant concentration of soluble 
carbohydrate, nitrogen, and various minerals for production of laccase enzyme. Different substrate used for SSFis sugarcane bagasse, corn stalk, rice straw, saw dust and rice husk. Its synthesis doesnot require any additional low molecular weight cofactor as laccase is an extracellular enzyme which help its proper processing, purification processes with good stability.These agricultural waste products provides carbon and nitrogen sources for fungal growth and production of laccase in SSF. Surface solid materials are used for microbial process via SSF by using organic and synthetic material. Physical characteristics of support system like shape, particle size, and consistency are directly related to the success of the process. Smaller size of particles are able to provide larger surface area for microbial growth by forming colonisation. Chemical composition of organic materials plays an important for success of SSF.

Basidiomycetous specifically white rot fungi, have ability to utilise lignin and cellulosic substances for their growth and production of laccase enzymes [4]. Higher titres of laccase are associated with SSF as fed-batch cultures with higher concentration of oxygen and slow sugar supplying process. SSF overcomes several problems such as $\mathrm{pH}$, agitation, aeration and temperature which are encountered in submerged fermentation (SF). Roy et al., 2006 reported SSF are able to utilize rubber biodegradation efficiently than the SF. Several reports from various authors emphasis on SSF in terms of high yield quality of product and downstreamingof product. Fermentation process is carried out with sufficient available water but without availability of free water for different agro-industrial lignocellulosic waste like rice bran, wheat straw, wheat bran and many more. Fermentation for production of laccase depends on many physical and chemical cultural conditions like nature of agronomic waste, content of carbon, nitrogen, amino acid, vitamins, metal ions composition source present, temperature, $\mathrm{pH}$, presence of inducers and aeration.

\section{MATERIAL AND METHODS}

\section{A. Organism and inoculum preparation}

\section{FungusPleurotusostreatusand}

Pseudolagarobasidium acaciicola obtained from the premises of Aurangabad was maintained onPDA (Potato Dextrose Agar) agar slants and from these slants inoculum was prepared for production of laccase enzyme. 5 grams of different substrate like rice bran, rice husk, wheat bran andwheat strawwas autoclaved in washed petri plates. Autoclaving was carried at $121 \mathrm{C}^{\circ}$ by keeping pressure at $151 \mathrm{~b}$ for 20 minutes. $10 \mathrm{mM}$ Sodium-acetate buffer solution of $\mathrm{pH} 5.5$ and Carbonate bicarbonate buffer solution at $\mathrm{pH}$ were applied on substrate which act as a moistening medium for fungal growth to maintain desired $\mathrm{pH}$ for fermentation. After incubation, Laccasewas harvestedfrom $P$. Ostreatusby adding $20 \mathrm{ml}$ distilled waterand the slurry was filtered by muslin cloth to remove all spores and other impurities. The collected supernatant was subjected to Laccase assay.For production of Laccase from $P$. ostreatus, the incubation time for rice bran was 13 days, for rice husk 10 days, for wheat bran 13 days and for sugarcane bagasse6 days. For laccase production the incubation of $P$. acaciicola, with different substrate for productions from rice bran was 11 days, for rice husk 9 days, for wheat bran 12 days and for sugarcane bagasse its 6 days incubation time as shown in table 1. Enzyme assay activity was checked byspectrophotometrically. 0.8 $\mathrm{mm}$ agar piece on which actively growing fungal mycelium was used as inoculum. After thoroughly mixing contents in petri plates were then incubated at $30^{\circ} \mathrm{C}$ in static conditions.

\section{Table 1.Represents the different incubation time by different substrate for Laccase production}

\begin{tabular}{|l|l|l|l|l|}
\hline \multirow{2}{*}{$\begin{array}{l}\text { Fungal } \\
\text { Species }\end{array}$} & \multicolumn{4}{|l|}{$\begin{array}{l}\text { Incubation time (days) for } \\
\text { production of laccase enzyme }\end{array}$} \\
\cline { 2 - 5 } & $\begin{array}{l}\text { Rice } \\
\text { bran }\end{array}$ & $\begin{array}{l}\text { Rice } \\
\text { husk }\end{array}$ & $\begin{array}{l}\text { Wheat } \\
\text { bran }\end{array}$ & $\begin{array}{l}\text { Sugarcane } \\
\text { bagasse }\end{array}$ \\
\hline P.ostreatus & 13 & 10 & 13 & 6 \\
\hline $\begin{array}{l}\text { P. } \\
\text { acaciicola }\end{array}$ & 11 & 9 & 12 & 6 \\
\hline
\end{tabular}

\section{B. Laccase assay activity}

Oxidation of ABTS method is used to determine the enzyme activity of laccase[3].Spectrophotometrically increase absorbance at $420 \mathrm{~nm}$ for 3 mins, which was related to the oxidation od 2, 2-azino-bis-3-ethylbenzthiozoline-6- sulfonic acid (ABTS). Reaction mixture contain $100 \mu 1$ of $50 \mathrm{mM}$ ABTS, $800 \mu$ of $100 \mathrm{mM}$ sodium acetate buffer at 
$\mathrm{pH}=5.0$ and $100 \mu 1$ of laccase enzyme extract. 420 $\mathrm{nm}$ absorbance of sample was taken against blank.

\section{RESULTS}

In present study, two different fungi e.g., $P$. ostreatusand $P$. Acaciicolawere allowed grown on different substrates likerice husk, rice bran, wheat bran and sugarcane bagasse. These fungi were able to produces good amount of laccaseenzymeby effectively degrading lignin by lignin degrading enzyme system.Different concentration of enzyme was produced on different substrate are shown in table 2.P.ostreatusgrown on different substrates in which rice bran $(0.32 \mathrm{~g} / \mathrm{ml})$ showed highest production of laccase enzyme followed by sugarcane bagasse $(0.30 \mathrm{~g} / \mathrm{ml})$, wheat bran $(0.25$ $\mathrm{g} / \mathrm{ml})$ and rice husk $(0.15 \mathrm{~g} / \mathrm{ml}) . P$. acaciicolaalso produce different amount of enzyme on different substrate. For rice bran enzyme concentration was $(0.27 \mathrm{~g} / \mathrm{ml})$, rice husk $(0.10 \mathrm{~g} / \mathrm{ml})$, wheat bran $(0.29 \mathrm{~g} / \mathrm{ml})$ and for sugarcane bagasse $(0.9 \mathrm{~g} / \mathrm{ml})$ as shown in Table 2.

Laccase assay activity different along with the substrate produced by two different fungi.Laccase produced by P.ostreatusin rice bran showed maximum activity on 13 th day $(3.9 \mathrm{U} / \mathrm{L})$, for rice husk 10th day (1.0 U/L), for Wheat bran 13th $(2.9$ $\mathrm{U} / \mathrm{L})$ and for sugarcane bagasse 6 th $(3.0 \mathrm{U} / \mathrm{L})$ at $\mathrm{pH}$ 5.5. $P$. acaciicolaenzyme activity at $\mathrm{pH} 5.5$ was maximum on 11 th day for rice bran $(1.2 \mathrm{U} / \mathrm{L})$, for rice husk on 9thday $(0.4 \mathrm{U} / \mathrm{L})$, for wheat bran on $12^{\text {th }}$ day $(1.1 \mathrm{U} / \mathrm{L})$ and for sugarcane bagasse on 6th day was $1.5 \mathrm{U} / \mathrm{L}$ as shown in Table 3 .

\section{DISCUSSION}

P. ostreatus and P. acaciicola fungi's are producer of extracellular laccase with different concentration and activity. Laccase enzyme was produced higher in case of rice bran substrate than the other substrates used for laccase production. Rice bran contain many phenolic compounds like vanillic acid and ferulic acid, which have ability to induce the production of laccase enzyme from $P$. ostreatus and $P$. acaciicola. Reference [13] studied different microbial sources can be used for production of laccase enzyme, mostly from white-rot fungi which have ability to degrade lignin. Reference [18] used dry, ground mandarin peels, grapevine and saw dust for production of laccase enzyme from $P$. ostreatus with concentration of laccase enzyme $0.333 \mathrm{~g} / \mathrm{ml}$ with $4.80 \pm 0.08 \mathrm{U} / \mathrm{L}$ as laccase activity. While for
$P$. acaciicoladecayed wood was used as a support system for laccase production and enzyme concentration was found to be $0.775 \mathrm{~g} / \mathrm{ml}$ with $6.9 \pm 0.4 \mathrm{U} / \mathrm{L}$ activity. The statistical optimization need to be carried to increase the production of laccase enzyme which will help to bio-eliminate the various agricultural and industrial phenolic waste compounds.

Table 2. Represents the different concentration of Laccase enzyme produced on different substrate

\begin{tabular}{|c|c|c|c|c|}
\hline \multirow[t]{2}{*}{$\begin{array}{l}\text { Fungal } \\
\text { Species }\end{array}$} & \multicolumn{4}{|c|}{$\begin{array}{l}\text { Enzyme concentration (g/ml) by } \\
\text { using different Substrates }\end{array}$} \\
\hline & $\begin{array}{l}\text { Rice } \\
\text { bran }\end{array}$ & $\begin{array}{l}\text { Rice } \\
\text { husk }\end{array}$ & $\begin{array}{l}\text { Wheat } \\
\text { bran }\end{array}$ & $\begin{array}{l}\text { Sugarcane } \\
\text { bagasse }\end{array}$ \\
\hline P.ostreatus & 0.32 & 0.15 & 0.25 & 0.30 \\
\hline $\begin{array}{l}P . \\
\text { acaciicola }\end{array}$ & 0.27 & 0.10 & 0.29 & \\
\hline \multicolumn{5}{|c|}{$\begin{array}{l}\text { Table } 3 \text {. Represents the enzyme activity of } \\
\text { Laccase enzyme produced on different } \\
\text { substrate }\end{array}$} \\
\hline \multirow[t]{2}{*}{$\begin{array}{l}\text { Fungal } \\
\text { Species }\end{array}$} & \multicolumn{4}{|c|}{$\begin{array}{l}\text { Enzyme activity (U/L) produced by } \\
\text { different substrates }\end{array}$} \\
\hline & $\begin{array}{l}\text { Rice } \\
\text { bran }\end{array}$ & $\begin{array}{l}\text { Rice } \\
\text { husk }\end{array}$ & $\begin{array}{l}\text { Wheat } \\
\text { bran }\end{array}$ & $\begin{array}{l}\text { Sugarcane } \\
\text { bagasse }\end{array}$ \\
\hline P.ostreatus & 3.9 & 1.0 & 2.9 & 3.0 \\
\hline $\begin{array}{l}P . \\
\text { acaciicola }\end{array}$ & 1.2 & 0.4 & 1.1 & 1.5 \\
\hline
\end{tabular}

\section{REFERENCES}

[1] Akpina M and R OzturkUrek (2017). Induction of fungal laccase production under solid state bioprocessing of new agroindustrial waste and its application on dye decolorization. Biotech; 7: $98 . \quad$ DOI 10.1007/s13205-017-0742-5.

[2] BlanquezP, SarraM, and M. T. Vicent (2006). Study of the cellular retention time and the partial biomass renovation in a fungal decolourisation continuous process. Water Research; 40 (8): 1650-1656.

[3] Bourbonnais R, Leech D and M. G. Paice (1998). Electrochemical analysis of the interactions of laccase mediators with lignin model compounds. BiochimicaetBiophysicaActa; 1379(3): 381-390.

[4] Chen HY, Xue DS, Feng XY and SJ Yao (2011). Screening and Production of Ligninolytic Enzyme by a 
Marine-Derived Fungal Pestalotiopsis sp. Appl. Biochem. Biotechnol; 165: 1754-1769.

[5] CoutoSR and JLToca-Herrera (2007). Laccase production at reactor scale by filamentous fungi. Biotechnology Advances; 25(6): 558-569.

[6] CoutoSR, MoldesD, LiebanasA, and A. Sanroman (2003). Investigation of several bioreactor configurations for laccase production by Trametesversicolor operating in solid-state conditions. Biochemical Engineering Journal; 15(1):21-26.

[7] DubeE, ShareckF, HurtubiseY, DaneaultC, and M. Beauregard (2008). Homologous cloning, expression, and characterisation of a laccase from Streptomyces coelicolor and enzymatic decolourisation of an indigo dye.Applied Microbiology and Biotechnology; 79 (4): 597-603.

[8] FaracoV, GiardinaP, PalmieriG and G. Sannia (2002). Metalactivatedlaccase promoters. Progress in Biotechnology; 21: 105-111.

[9] Niku-Paavola ML, Karhunen E, Kentelinen A, Viikari L, Lundell T and A Hatakka (1990). The effect of culture conditions on the production of lignin modifying enzymes by the white rot fungus Phlebiaradiata. $J$ Biotechnol;13:211-221. doi:10.1016/0168-1656(90)90106-L.

[10] Roy RV, DasM, Banerjee R and AK Bhowmick (2006). Process Biochemistry; 41: 181.

[11] Schliephake K, Mainwaring DE, Lonergan GT, Jones IK and WL Baker (2000). Transformation and degradation of the disazo dye Chicago Sky Blue by a purified laccase from Pycnoporuscinnabarinus. Enzyme MicrobTechnol; 27: 100-107.

[12] SedaratiMR, KeshavarzT,.LeontievskyAAand CS Evans (2003). Transformation of high concentrations of chlorophenols by the white-rot basidiomyceteTrametesversicolor immobilized on nylon mesh. Electronic Journal of Biotechnology; 6 (2): 27-37.

[13] Shraddha, Ravi Shekher, SimranSehgal, MohitKamthania, and Ajay Kumar(2011) Laccase: Microbial Sources, Production, Purification, and Potential Biotechnological Applications. Enzyme Research Volume 2011, Article ID 217861, 11 pages. doi: $10.4061 / 2011 / 217861$

[14] Songulashvili G, Elisashvili V, Wasser SP, Nevo E and Y Hadar (2007). Basidiomyceteslaccase and manganese peroxidase activity in submerged fermentation of food industry wastes. Enzyme Microb. Technol; 41: 57-61.

[15] Szabo OE, Csiszar E, Toth K, Szakacs G and B Koezka (2015). Ultrasound-assisted extracted and characterization of hydrolytic and oxidative enzymes produced by solid state fermentation. UltrasonSonochem; 22: 249 - 256.

[16] TongP, HongY, XiaoY, ZhangM, TuX, and T. Cui (2007). High production of laccase by a new basidiomycete. Biotechnology Letters; 29(2): 295-301.

[17] Upadhyay P, Shrivastava R, Agrawal PK (2016). Bioprospecting and biotechnological applications of fungal laccase. Biotech; 6:189-199.

[18] Wang Feng, Ling Xu, Liting Zhao, Zhongyang Ding, Haile $\mathrm{Ma}$ and Norman Terry (2019) Fungal Laccase Production from Lignocellulosic Agricultural Wastes by Solid-State Fermentation: A Review. Microorganisms; 7: 665. doi:10.3390/microorganisms7120665.

[19] Xiao YZ, Tu XM, Wang J, Zhang M, Cheng Q, Zeng WY and YY Shi(2003). Purification, molecular characterization and reactivity with aromatic compounds ofa laccase from basidiomyceteTrametes sp. strain AH28-2. ApplMicrobiolBiotechnol;60: 700-707. 